\title{
Towards gender equality in family forestry: building self-efficacy together with other female forest owners
}

\author{
Katri Hamunen ${ }^{a}$, Hanna Muttilainen ${ }^{b}$, Jukka Tikkanen ${ }^{c}$ and Teppo Hujala ${ }^{c}$ \\ aBioeconomy and Environment, Natural Resources Institute Finland Joensuu, Joensuu, FI, Finland; \\ ${ }^{b}$ Bioeconomy and Environment, Natural Resources Institute Finland Joensuu, Mikkeli, Finland; \\ 'Faculty of Science and Forestry, School of Forest Sciences, University of Eastern Finland, Joensuu, \\ Finland
}

Contact: Katri Hamunen, katri.hamunen@luke.fi, Bioeconomy and Environment, Natural Resources Institute Finland Joensuu, Yliopistokatu 6B, Joensuu, FI 80101, Finland

\begin{abstract}
:
The share of women among forest owners is growing in the traditionally masculine family forest sector. The present study continues the research on women who own forest in the Nordic setting. The focus is on the behaviour and role of rural female forest owners in Finland, as well as on the benefits of peer learning when building self-efficacy as a forest owner. The qualitative data consist of interviews with female forest owners, peer-learning group observations and feedback. The studied female forest owners who participated in the peer-learning group focused on silvicultural actions on the home farm. These women were eager to learn, but uncertain about their experience and capabilities as forest owners, which reduced their confidence to participate in forest-related discussions outside the home farm. The responsibility and decision-making power regarding the forest property is, in many cases, given to the husband. Within the studied group, the desired aim of learning seems to be the same silvicultural and timber production-oriented knowledge as held by male forest owners. In order to create new ideas and even business opportunities, the facilitator of peer-learning group plays an important role in encouraging participants to take part in more diverse discussions.
\end{abstract}

Keywords: family forest owners, forestry, gender, mastery experience, peer learning

To cite this article: Katri Hamunen, Hanna Muttilainen, Jukka Tikkanen \& Teppo Hujala (2020):

Towards gender equality in family forestry: building self-efficacy together with other female forest owners, Scandinavian Journal of Forest Research, DOI: 10.1080/02827581.2020.1843702

To link to this article: https://doi.org/10.1080/02827581.2020.1843702 


\section{Introduction}

In Europe, the share of female forest owners is around 30\% (Follo et al., 2017). In Finland, this share is around $41 \%$, and has remained at this level during the past 10 years (Karppinen et al., 2020). This figure takes into account the fact that the male owners of the commonly owned forest holdings typically reply to the questionnaires from which statistics of this kind are collected (Karppinen and Hänninen, 2017). In studies on Nordic-Baltic family forest ownership and owner management behaviour in the late 1990s (Brandth and Haugen, 1998; Lidestav, 1998; Lidestav and Wästerlund, 1999; Lidestav and Ekström, 2000), gender was introduced as a category that creates structure and carries meaning. Subsequently, masculine features, such as male presumptions (perceptions that forestry is man's duty rather than woman's), and appreciation of strength and effectiveness have been reported to historically and culturally shape the social system of family forestry. The dominance of masculine features can be seen in a number of ways, such as in inheritance practices (Lidestav, 2010), biodiversity conservation (Vainio and Paloniemi, 2013; Umaerus et al., 2019), timber sales (Umaerus et al., 2013; Kuuluvainen et al., 2014; Butler et al., 2017), timber stand improvement (Karppinen and Berghäll, 2015) and financial risk taking (Andersson et al., 2010; Eriksson, 2018). According to previous research in a north European context, women carry out less silvicultural work, such as planting, and less often harvest forest than men (Lidestav and Nordfjell, 2005; Lidestav and Berg Lejon, 2013; Häggqvist et al., 2014). Moreover, in Sweden, the values and interests of female forest owners have been found to differ from those of male forest owners (Umaerus et al., 2019). According to a recent US study, gender has an influence on forest owners' internal belief in his or her ability to accomplish tasks (Markowski-Lindsay et al., 2020). In that study, compared to men, female forest owners rated themselves as being less prepared, less confident and financially not as less capable of moving forward with planning the future of their land.

Alongside the above observations and analyses on gendered features in family forestry, recognition of female forest owners has been associated with initiating special events and new activity forms targeted at these owners. Networks of female forest owners have been established and researched in both the US and the Nordic countries (Redmore and Tynon, 2011; Andersson and Lidestav, 2016). While the US experience highlights peer-to-peer 
communication opportunities as comfortable and welcoming learning environments (Huff, 2017), at Swedish analysis recognised women's networks as vehicles to expand the discursive space, empowering their members not only as individual forest owners but also as contributors to gender equality policy (Andersson and Lidestav, 2016). However, a Norwegian analysis (Brandth et al., 2004) recognised dilemmas in establishing separate organizations for women and suggested avoiding a feminist label, instead seeking alliances with men.

A person's identity is constantly built in interaction with other people, in which the role of "similar others", i.e. peers, is essential (see McPherson et al., 2001). People tend to form ties with those who are similar to them, and these homogeneous peers influence their behaviour (McPherson et al., 2001). Several studies have supported the idea that peer forest owners can play a role in the decision making of family forest owners (West et al., 1988; Knoot and Rickenbach, 2011; Ma et al., 2011; Schubert and Mayer, 2012). Based on recent empirical research on peer-to-peer learning among family forest owners (Kueper et al., 2013; Hamunen et al., 2015; Markowski-Lindsay et al., 2020), we suggest that the interaction of female forest owners with their local female peers could contribute to their self-efficacy and activeness as forest owners, encourage them to participate in forest related issues and give them a stimulus to make decisions regarding their forest property, thus also promoting societal gains in the form of diverse and active use of forests for multiple benefits.

This study seeks to obtain a deeper understanding of the perceptions and behaviours of female forest owners in a peer-learning network. In particular, the study focuses on how the participants in peer-learning groups learn, share information and feel in these meetings, as well as on the benefits of type of networking when building self-efficacy. Self-efficacy and the sense of being peers with each other are examined in the practical actions of female forest owner networks and then discussed from the gender perspective to connect with the co-construction of transformative and inclusive policies (Wood and Bandura, 1989; Bandura, 1997). In this study, we hypothesise that strengthening the self-perception of female forest owners as sovereign and capable forest owners may lead to improved care and responsibility for forest properties. Therefore, we see reason to further explore the role of female forest owners in present-day Finland (see West and Zimmermann, 1987, 2009) and 
how the peer-learning networks of female forest owner can strengthen their role as active forest owners.

Essentially, this study aims to address two issues. The first of these is being a female forest owner in the rural context in Finland, as well as the mastery experiences, i.e. earlier experiences, that these owners have. Secondly, we examine the possible benefits of peer learning among these female forest owners. Self-efficacy and mastery experiences (Bandura, 1977; Wood and Bandura, 1989) are used as theoretical concepts, and they are described in more detail in the next section. The precise research questions are as follows:

1. What kind of role do female forest owners play, and what types of activities do they perform?

2. Can peer learning lead female forest owners to gain new mastery experiences and to build their self-efficacy?

\section{Theoretical background}

Gender makes a difference in society. In particular, gender becomes a relevant factor in spheres that have historically and culturally been shaped by gendered or masculine or feminine requirements, assumptions and stereotypes (see e.g. Follo et al., 2017). Forestry and forest ownership have been seen as predominantly masculine spheres, providing easy environments for men and more challenging positions for women (Andersson and Lidestav, 2016; Johansson et al., 2019). Responding to the suppressed situation of women with institutionalised tools and techniques carries the potential consequence that women may lose the opportunity for political transformation (Resurreccion and Elmhirst, 2012). When environmental, natural resource and forest policies take gender as an inclusion challenge to safeguard female representation, the gender equality endeavour narrows to a technocratic exercise (Arora-Jonsson, 2014). It has been suggested that the inadequately impactful "gender mainstreaming" (policy approach of assessing and ensuring equal opportunities for men and women on all planning and activity levels) should be replaced by "diversity mainstreaming" (Hankivsky, 2005), opening avenues for a wider understanding of inequalities and hegemonies in the social system, often referred to as an intersectional approach to feminism. Bacchi and Eveline (2010) essentially follow these lines but further 
argue that rather than debating on appropriate labels for equality activities, the focus should be directed towards women's voices to steer transformation, as well as towards the processes and practices that give an initiative content and shape, i.e. the politics of 'doing'. In the forestry sector, these activities could include gender impact assessments of forest policies, equality campaigns in forest owner organizations, and gender-equal service design projects. These 'doings' are advised to be inclusive and democratic with the aid of 'coalitions of engagement', i.e. groups committed to cooperating towards egalitarian politics, and 'deep listening', i.e. contemplating in real time what you hear and showing respect through what you do (Bacchi and Eveline, 2010).

Bandura presented the self-efficacy theory back in 1977, and it has been further developed since then (e.g. Wood and Bandura, 1989; Bandura, 1997). Self-efficacy is an individual's internal belief and motivational construct of his or her abilities. This belief has an effect on an individual's actions and performance and it restricts or motivates the choice of activities (Wood and Bandura, 1989) and is essential in learning (Zimmerman, 2000). Self-efficacy is formed throughout life, but self-efficacy in adolescence, formed with the family and at school, can have an effect on the whole life (Bandura, 1997; Pajares, 2002; Schunk and Meece, 2006). Nevertheless, gender has an influence on it (Pajares, 2002). In general, women have lower self-efficacy, for example, in mathematics (Pajares, 2002), and furthermore in life in occupations that are male dominated (Hackett and Betz, 1981), including forest ownership (Markowski-Lindsay et al., 2020) and among forest professionals (Johansson et al., 2019).

The factors of building self-efficacy include mastery experiences, vicarious experiences, social (verbal) persuasion and physiological factors (Bandura, 1997). Mastery experiences refer to earlier experiences. The positive feeling of having had control in earlier experiences reinforces people's beliefs in their abilities in similar situations, and vice versa. In this study, mastery experiences refer to experiences of females as forest owners, and the feeling that they did or did not have control in these situations. Vicarious experiences are the examples from others who, despite differences, are somehow similar and thus provide meaningful comparisons. Observing successful examples or models from these benchmark people can increase people's beliefs in their own abilities. Here, the assumption is that the people 
providing meaningful examples are other female forest owners, i.e. peers, whose vicarious experiences can support female forest owners in building self-efficacy.

Verloo (2005) articulates gender mainstreaming as a strategy of empowerment via organising space for non-hegemonic actors to promote the agenda of gender equality. This thinking is in line with the analysis of Andersson and Lidestav (2016), who recognised the prevalent tasks for networks of Swedish female forest owners to create alternative discursive spaces where male domination is masked and more equal communication is possible. They (ibid.) also called for more careful listening to the needs of female forest owners. What follows from here is the delicate task of providing opportunities for and enabling and supporting such activities of 'doing gender' (acting in everyday settings according to gendered role expectations, as introduced by West and Zimmerman (1987)) that take up the transformative potential among the actors. In such a transformation, one may be and act as a woman and still be an equal forest owner. Peer learning creates the type of space, or safe environment, where the factors that build self-efficacy can be found (Topping, 2005). Peers are people who belong to a relatively homogeneous group, for example in terms of background characteristics, experiences or social grouping, and have somehow similar identities (Eisen, 2001; McPherson et al., 2001). Sufficiently, similar peers are influential sources of vicarious experiences and social persuasion. When showing and telling examples to others in a peer group, a person repeats the successful actions in her mind, and this might raise belief in her own abilities (mastery experiences). In everyday life, we define ourselves according to different identity categories. These categories are typically built in the same way again and again (Suoninen, 2012). Purposeful peer learning may create a type of interaction that differs from everyday life and in this way provides courage for new types of behaviour and even for a change in how a person identifies herself.

Lidestav contemplated (2010) the role of female forest owners as inheritors and managers of family-owned forestland. Her analysis followed the notion by Törnqvist (1995) of Swedish small-scale forestry as 'a project that spans generations' and Flygare's $(1999,2001)$ conceptualisation of two dimensions specifying the role of the woodland inheritor: transitive versus transformative and element versus agent (Fig. 1). Female forest owners may be categorized into one of four possible types. In the first type, a woman may be given the position, e.g. because there is no man to take the position in the current circumstances. 
Practices are carried out and the forest is managed in the same way as by previous generations (transitive element, TE). According to the second type, a woman may actively and purposefully take a more decisive and active role, but behave according to prevalent norms (in the same way as men behave) (transitive agent, TA). Third, a female inheritor may be given the forest in the prevailing conditions, and may take the opportunity to look at the forest with her own eyes and interests (transformative element, TFE). Fourth, she may take forest ownership as a part of her identity and actively challenge the traditional practices (transformative agent, TFA). In this study, signs of these four ideal types among female forest owners may provide insights into how the gender mainstreaming -oriented policies and 'doing gender' practices have succeeded in giving space, voice and empowerment to owners who, in the Nordic countries, have traditionally been in non-hegemonic or even suppressed positions.

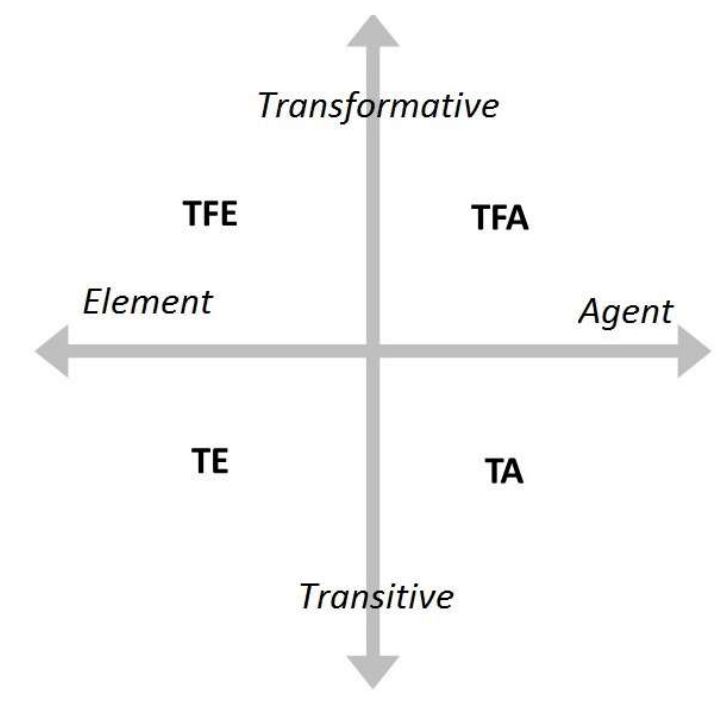

Figure 1. Two-dimensional conceptualisation that specifies the role of female woodland inheritors (adopted from Lidestav, 2010).

\section{Material and Methods}

\section{Study settings}


We conducted our study on a group of female forest owners $(n=15)$ in the northern Savo region of Finland, where women live in the same rural municipality close to their holdings. The women were forest owners themselves, either alone or together with their husbands, or their husbands were the official owners and the women were participated in forestry work. The group had its roots in a local association of the Rural Women's Advisory Organization, and they had earlier formed a network and, for example, organised a course on how to use a clearing saw (better known as brush saw in the US). Between spring 2015 and autumn 2017, under the auspices of the current research intervention, the women gathered for forest-related meetings.

In the first meeting, a collaborative brainstorming session was organised to gather and list information on the starting situation and the group members' wishes concerning the upcoming networking activities. As a general wish, the group wanted to visit each other's forests, hear about the management history and plans and invite topic specialists to give short presentations and answer further questions. Altogether, the group held 10 meetings: six forest walks and four classroom "lectures". The meetings focused on silvicultural issues such as regeneration, pre-commercial harvesting and fertilisation as well as forest damage, biodiversity protection, intergenerational land transfer, e-services and forest-related taxation. There were 5-24 participants in each meeting. In some of the meetings, such as the one on intergenerational land transfer, additional family members were welcomed, which increased the number of participants. The meetings were facilitated by a forest extension specialist, whose task was to create a forum for women to discuss forest-related issues and learn from each other.

In addition to the group of female forest owners, there were also two parallel mixed-gender groups in which the focus was peer learning. One mixed-gender group consisted of forest owners in a sparsely populated area and the other of forest owners living in the Helsinki metropolitan area far from their forest holdings. The outcomes of interviews with these two groups were used as secondary data to obtain a broader view of the role and position of female forest owners in Finland. 


\section{Data and analysis}

From the group and meetings, four sets of data were collected:

Dataset 1, interviews with forest owners 1-7 (FO 1-7): The seven women who most actively participated in the meetings were interviewed after the sixth meeting (at the end of 2016) (Appendix 1). Besides these individual interviews, a group interview was conducted with three women. The interviews, which were carried out both face-to-face and by phone, were semi-structured, and the interviewee rather freely talked about different themes. The interviewer asked supplementary questions or reverted to a previous theme (Wengraf, 2001). The interviews lasted from $30 \mathrm{~min}$ to $1 \mathrm{~h}$, and they were recorded and transcribed. The individual interviews considered peer learning and forest ownership by females, as well as gender issues in forest ownership, while the group interview focused on the latter theme (Appendix 1).

Dataset 2, observations: During the meetings, a silent observer took instant field notes about what happened and how the interaction was distributed among the group. Participants in the discussions during the meeting, the topics and tone of discussions, the atmosphere of the meeting, group dynamics and facilitation aspects were observed in the field. Based on the field notes, the observer summarised the meeting on a separate form and this form was used in the analysis phase.

Dataset 3, feedback: Starting from the second meeting, the participants completed a feedback form that enquired about their motivation, learning, feelings, suggestions and knowledge transfer aspects of the meeting.

Dataset 4, interviews with forest owners 8-12 (FO 8-12): Three men and two women from the mixed-gender peer learning groups were interviewed. These interviews had the same themes and were treated in the same way as the interviews with the female forest owner group.

Thematic coding was used to analyse the data from the interviews and observations of the peer group meetings (Datasets 1, 2 and 4). The qualitative data analysis software NVivo was used as a tool to condense, classify and code the data (Bazeley and Jackson, 2013). First, 
coding classes were created based on the theoretical background (Appendix 2). At first, the interviews and observations were read through, and coding classes based on the theoretical background were formulated after the first coding, since new aspects arose from the data. The new classes were used in the second coding. Third, triangulation of two researchers was used; the first researcher carried out the preliminary coding and the second researcher read the coded text and expressed her ideas and suggestions. Changes to the coding were discussed. The results of the feedback forms (Dataset 3) were quantitative. Means were calculated from the scores for receiving and giving information during the meeting.

\section{Results}

\section{Mastery experiences: roles and actions of female forest owners}

\section{Limited responsibility}

The roles of the interviewed women as forest owners varied from acting as an "idea-sharing companion" for the husband (FO 4) (interviewed forest owner number 4) to those who were the only and sovereign owners of their holdings (FO 2, FO 3, FO 7, FO 8). In many families, even though women were the official forest owners, together with their husbands, the husband was the main forest owner, since he conducted, and had traditionally been conducting, most of the forest work (FO 1, FO 2, FO 4, FO 5, FO 6). All the interviewed women were active and interested, and they did discuss forest issues with their husbands. However, during the interviews, women reported examples from their own lives or the lives of their friends and relatives, in which responsibility had been given to the husband or a male relative (FO 1, FO 3, FO 2). According to these examples, female forest owners did not dare, did not feel that they had enough expertise, or were not interested in taking responsibility for their forests.

Some interviewees reported that they made decisions regarding their forest together with their husbands or brothers (FO 1, FO 2, FO 4). Making decisions alone seems to have been difficult for some women (FO 3, FO 4). Especially concerning timber sales, it was customary 
in several families that the husbands made the decisions (FO 1, FO 2), and in some cases, the women were not even asked (FO 4, FO 12). On the other hand, two women who participated in the mixed-gender peer learning groups said that they felt comfortable with taking responsibility and making decisions by themselves (FO 8, FO 11). Although they no longer "needed" women-only groups for themselves, they understood the benefit if other women wanted to have this type of group. One message from them was that women need to take their place by themselves; it is not given to them. One woman had owned forest together with her sisters, who were not interested in forest-related issues (FO 3). Based on her interview, the process of taking responsibility for the forest holding had not been easy and she felt lonely. However, she saw that she had already advanced in the process of building self-efficacy, and found forest ownership rewarding.

\section{He knows better, but she is eager to learn}

Based on the interviews and observations, it could clearly be seen that the interviewed women were eager to learn about forests and silvicultural issues, and they had no doubts about their ability to learn (FO 1, FO 2). "I was really taking it [information] in" (FO 4), one of the women stated. In the interviews, women highlighted their willingness to obtain new information, and all of them pointed out that during the meetings they could learn new skills. In particular, those women who were the only owners of their holdings wanted to be sure that they had enough information on which to base their decisions.

Most of the interviewed women thought that men have greater knowledge about forests, mainly because men have traditionally spent more time in forests (FO 2, FO 5, FO 6, FO 7). Through experience, men have acquired more information and skills, for example related to timber sales and silviculture. One woman noted: "Of course, those men, they do know the right tree species for every kind of soil" (FO 2). According to the interviewed women, forests have traditionally been men's world, and this was seen in many families (FO 2, FO 4, FO 6). One of the elderly women described the traditional roles as follows: "Since women have everything else to do as well, if there is a man in the house, it is he who goes into the forest" (FO2). In two peer-learning meetings, the role of the host was given to the husband, since 
"he knows better" and was more aware of the actions conducted in the forest holding (FO 6, observations).

Several women noted that according to their beliefs, in forest-related issues, women generally have "softer" values, which means that women act in more environmentally friendly ways and their goals are more recreation-oriented than those of men (FO 5, FO 6, FO 7). Men's way of making decision was thought to be more straightforward, and monetary income was seen as a more important goal for them (FO 7, FO 12). On the other hand, one of the interviewed women (FO 6) highlighted that the purpose of owning forest is not dependent on gender, but rather on the situation, namely whether the forest is the main source of income or more of a venue for leisure activities.

\section{Planting seedlings and conducting pre-commercial harvesting}

Planting tree seedlings and conducting pre-commercial harvesting with a clearing saw were seen as typical forest activities for these women (FO 1, FO 2, FO 5, FO 6, FO 7). An elderly woman mentioned that earlier, decades ago, her father had done all the forest work and she had helped him, and in those days, even her helping was an exception, since it was not a customary for women to participate in forest work (FO 2). She noted that nowadays, planting seedlings is her "favourite work". Another woman was eager to conduct precommercial harvesting with a clearing saw and explained that she needs to ask her husband to point out forest areas, that are appropriate for her skills (FO 6). This example illustrates that the main responsibility and up-to-date knowledge are in the hands of the husband. In the most extreme case, an interviewed woman described that her forest work was the work done in the kitchen (FO 4). Three women stated that they had experience of working with a chain saw (FO 2, FO 7, FO 11), while such experience was seen as exceptional among the other women. Once, one of these women (FO 2) had cut up trees that had fallen across a road to enable cars to pass. Male drivers, unfamiliar to her, were surprised to see a woman working with a chain saw. This example illustrates the belief that was also verbalized in the interviews, namely that men have better knowledge of machinery and greater physical strength to conduct forest work (FO 1, FO 3). 


\section{Discussions between men}

Generally, women considered that they were served well when they contacted forestrelated service providers (FO 2, FO 3, FO 4, FO 7). This was especially the case when women were alone in the service situation. If both the husband and wife were available, or if the service provider was about to call one of the owners, he generally directed his comments to the husband (FO 6, FO 11). This was especially the case when agreeing on about timber sales and when the service providers were elderly (FO 6, FO 7) "Elderly men [service providers] tend to talk mainly to him [husband], even if we are both sitting around the same table" (FO 6). This type of behaviour was also seen when observing the peer learning meetings; if both the wife and husband were in the forest, the male extension specialist, who was invited to the meeting directed his questions and comments more frequently to the husband (meetings with FO 6, observations). Women were uncertain whether to participate in the common discussion during the events arranged for forest owners, since they felt that they did not have sufficient knowledge (FO 3, FO 6) "If they need to listen to these, let's call them dumb questions, something self-evident, it may make you a bit shy so you won't participate in the discussion that much" (FO 3). Therefore, discussions among men controlled the extension events (FO 2).

\section{Increasing appreciation}

The interviewed forest owners noted that in the past, the involvement of daughters and wives in forest issues was not appreciated (FO 10, FO 12) and they were ignored (FO 3). However, according to a male forest owner from the mixed-gender group (FO 10), the situation has changed, and when speaking about the inheritance process, he noted that "I don't think that there is a need to pass the holding on to a son rather than a daughter". Many of the interviewees considered that women had not traditionally been included in forestry (FO 3, FO 5, FO 12), but that nowadays, gender no longer plays such a large role (FO 1, FO 5); this change is ongoing (FO 11). In the first peer meetings, the hosting women wanted their husbands to be present, and these male owners of the visited holding played a greater role when presenting their forest, but as the meetings continued, the role of the hosting women increased (observations). 


\section{Peer learning and its impacts on female forest owners}

\section{Feeling of not being dumb}

In the first meeting, the composition of the peer-learning group was discussed (observation 1). The women decided that they did not want men to participate in the meetings. An exception was the male owner of the visited forest holding. The women noted that men seem to be too all-knowing, especially in group extension situations (FO 2, FO 4, FO 7). According to the experiences of a woman who had participated in a mixed-group meeting, it requires courage to participate and express opinions about forest-related matters as a woman, since women are easily disregarded in traditional extension events (FO 11). Less experienced women were shy to participate in the discussion in mixed extension meetings, as they felt they did not know enough and asked foolish questions; for these reasons, they wanted to have their own group (FO 1, FO 4, FO 5, FO 6, FO 7). On the other hand, the interviewed men in mixed groups hoped that there would no longer be gender-related differences in forest issues and that women would participate in the mixed groups (FO 10, FO 12).

A similar level of knowledge, gender, age, a similar life situation, a small enough group, familiarity with the other group members and customary roles already existing inside the group were mentioned as factors that created a feeling of being a peer with other women in the studied group. None of the women were professionals in forest issues, and because of this, they dared to ask their questions and did not need to be ashamed because of their ignorance. They had a feeling that none of them was above the others. According to the women, if there had been more experienced male forest owners in the group, the feeling of being peers with one another would have been different (FO 4, FO 5, FO 7).

The atmosphere in the meetings was relaxed, which was obviously because the owners already knew each other. Everybody spoke, the group was active, and the tasks given to discuss in pairs proved successful in generating ideas and interaction between the owners. The facilitators had a significant role as moderators, giving everyone an equal opportunity to express their opinions, although some women wished that the facilitator could have 
encouraged opinion sharing even more (FO 5, FO 6). In free time, for example when walking from one forest area to another, discussion occurred spontaneously in smaller groups (observations). These discussions easily turned more towards the women's personal forestrelated interests, such as picking berries or mushrooms (observations, meeting 2 ). At the end of the forest walk, the group typically sat next to a fire, and the conversation was deep and thoughtful.

\section{Sharing and receiving information and experiences}

The topics of discussion between the owners included the practical work done in the visited forests. The owners both commented on the work done in the forests and reported their own experiences (observations). The owners shared their experiences openly with others, and one mentioned that it was good to notice that others have similar questions and problems concerning forestry (FO 4, observations). Even though the owners discussed among themselves, it was important for them to have the opinions of specialists to make sure that their knowledge regarding silvicultural actions was accurate. All of the interviewed women said that they had learned from both the professionals and the other forest owners. According to the feedback forms, the owners estimated that they had received slightly more information from the forest professionals than from the peer owners, and they further indicated that they had shared notably less information with others compared to the information they had received (Table 1). However, the hosting owners felt that they had shared more information than average. 
Table 1. Perceptions of female forest owners about receiving and giving useful information during the peer-learning meetings on a scale from 1-7 (1 not at all ... 7 very much). The higher the ratings, the more information was received or shared.

\begin{tabular}{c|c|c|c|c}
\hline $\begin{array}{c}\text { Meeting number } \\
\text { (number of } \\
\text { participants) }\end{array}$ & Settings of the meeting & $\begin{array}{c}\text { Information } \\
\text { from peers }\end{array}$ & $\begin{array}{c}\text { Information } \\
\text { from forest } \\
\text { professionals }\end{array}$ & $\begin{array}{c}\text { Information } \\
\text { shared with } \\
\text { others (host) }\end{array}$ \\
\hline $2(11)$ & Forest walk & 5.3 & 5.5 & $3.4(5)$ \\
\hline $3(7)$ & Forest walk & 5.4 & 5.9 & $4.1(6)$ \\
\hline $4(9)$ & Forest walk & 5.1 & 5.4 & $3.7(5)$ \\
\hline $5(7)$ & $\begin{array}{c}\text { Classroom presentation: } \\
\text { e-service }\end{array}$ & 6.0 & 6.3 & $3.9(3)$ \\
\hline $6(3)$ & $\begin{array}{c}\text { Classroom presentation: } \\
\text { taxation }\end{array}$ & 4.6 & 6.7 & 4.0 \\
\hline $7(11)$ & $\begin{array}{c}\text { Classroom presentation: } \\
\text { intergenerational land } \\
\text { transfer }\end{array}$ & 5.7 & 6.2 & 4.1 \\
\hline $8(9)$ & Forest walk & 5.3 & 5.8 & $3.5(6)$ \\
\hline $9(10)$ & Forest walk & 5.5 & 6.3 & 3.7 \\
\hline $10(7)$ & & 5.3 & 6.1 & 3.7 \\
\hline All & & & & \\
\hline
\end{tabular}

The women felt that the meetings increased their expertise regarding silviculture. The interviewed women emphasised that in the meetings, they had seen different types of forests and good examples from others' forests, which helped them to understand silvicultural issues. According to the women, listening to a lecture or reading a book is different from practical observation (FO 2, FO 3, FO 6). For example, a visual example of the impacts of different soils on silvicultural actions needed on a stand came up in many interviews. The women noted that they had learned that there is no one right way to do anything. One woman was strongly against the idea that new forest needs to be cultivated with plants or seeds every time, because she had good experience with natural regeneration (FO 6). This opinion was contrary to the invited expert's opinion, who was in favour of cultivation. Via these types of discussions, the women learned that professionals do not know everything, but experiences from peers can be valuable and teach important points. One of the women described how her narrow view of silviculture was based on the customs of the men in her family, but via the group, her view could be expanded (FO 1). 


\section{Gaining inspiration and courage}

Some women noted that the meetings did not have many practical consequences regarding their forests, as most changes cannot be realised very quickly in a forest, but the meetings certainly stimulated new thoughts (FO 1, FO 6). The first interviewed forest owner described how peer meetings in others' forests allowed her to see the actions that other women had taken in their forests, providing inspiration, for example to use a clearing saw in her own forest (FO1). A second woman had started to read more forest-related magazines (FO 6), while a third woman reported that the meetings stimulated her to take care of matters, for example to call service providers (FO 3). In a meeting, she learned that the timing of the precommercial harvest is important, and she wanted to discuss this with her service provider. A fourth woman was excited about the e-service presented and wanted to get to know the service together with her husband (FO 4).

All the interviewed women emphasised the positive atmosphere of the meetings. One of them felt that the meetings had strengthened their "team spirit" (FO 1). The women acknowledged how strong and multitalented the other members of the group were, which increased their respect for each other (FO 1, FO4). Via the group meetings, their knowledge increased, which gave them the courage to freely discuss forest issues (FO 1, FO 2). They were subsequently able to more readily share their own experiences and opinions, as well as participate in forest-related discussions in other contexts. The meetings had increased the feeling of being understood and appreciated in a group and outside the group. One of the women noted that after the group had visited her forest, she had a feeling that others understood her and her situation better; she now dares to make decisions regarding her forest (FO 3). Another woman noted how now that she knows about forest issues, she has a feeling of being more appreciated by her husband (FO 4). The women would also like to encourage other women to join these meetings (FO1, FO 6).

\section{Discussion}

The aims of this study were to determine the roles of the studied women as forest owners and to investigate the support that peer learning settings can provide for female forest 
owners when building their self-efficacy. Since the focus was on one peer learning group and the number of studied women was limited, the results are descriptive and cannot be generalised to represent all female forest owners in Finland. However, the observations may be considered to reflect the phenomena that probably exist and are relevant among rural women beyond the scope of the present case group. In the following, the results are discussed in a broader context.

\section{From element to agent via peer learning}

The interviewed female forest owners appeared to be eager to work on their own farm, but were uncertain about participating in forest-related discussions and decision making outside of the home environment. Even though the studied women were considered active within their family forest ownership, many of them had limited their role to accompanying their husband in forest work, discussions and making decisions. The husband was considered the "real" forest owner. Being a forest owner means being one together with their husbands, earlier noted as a bystander's position among Finnish female forest owners (Vainio and Paloniemi, 2009). According to this group, it is rare to have mastery experiences, for example in extension event discussions, in timber sales or in purchasing forest-related services. If there is a man in the family, women are hesitant to take a strong role in these situations. When comparing the results with the two-dimensional conceptualisation of Lidestav (2010), it seems that these women, despite the powerful role of their husbands, were more in the position of agents than elements. Most of them had actively taken and defined their roles on the home farm as forest owners, and participating in this type of group supports the idea of them actively taking this role (Fig. 2). The agent position is also highlighted via the observation that these women had not drifted into the active role, but had searched for one that was suitable for them.

The results indicate that the studied peer-learning group created a supportive, safe and relaxed environment. The group was interactive: the women shared opinions, asked questions and pondered alternatives together. They did not hesitate to speak in the group. These aspects are probably products of earlier social experiences within the familiar group, but most likely, the spirit of the group also originated from the fact that its participants were 
all women (Redmore and Tynon, 2010; Huff, 2017; Markowski-Lindsay et al., 2020). The meetings increased the women's knowledge, which led to a virtuous circle; by learning, the women also became more encouraged to participate in discussions outside the group. Even though the study period was short, the meetings activated the women in practice to some extent. In the case of one woman (FO 3), the increase of self-efficacy via the support of the peer group was reflected in the interview more clearly compared to the other women. This woman had felt lonely regarding her role in forestry, and the peer group had given her stimulus for actions. These are the signs of taking a more active role as a forest owner (Fig. 2 , trajectory number 1 ). Although the women had learned from each other, they were less familiar with and confident in sharing their own experiences. It is extremely important that peer-learning settings are of the type that give courage to share opinions, experiences and concerns when one does not feel like an expert. The facilitator of the peer group has an important task of asking questions, being interested and giving time to speak (Vehviläinen, 2014).

In this study, it remained unexamined whether the self-efficacy that female forest owners built up in the peer-learning group was sustained outside the group. Among female professionals working in forestry, feelings of exclusion due to homosocial interaction, as well as the need to prove one's own competence, are familiar (Johansson et al., 2019). However, female forest professionals are slowly changing the dominant discourse, and at best, this happens in the daily activities of forestry organisations and via alternative professional identities, such as service-oriented forestry work (Johansson et al., 2019). In the case of female forest owners, gaining mastery experiences and seeing vicarious experiences that other female forest owners have, especially outside the safe peer group environment, would be important. The more experienced female forest owners are in an important position to show that forest owners can be peers, regardless of gender. However, approaching gender equality via transformative politics would need the mastery experiences and successful group processes to disseminate the activity tone and spirit wider to the society, in political processes and activities in mixed-gender groups. The scope and objectives of this study were too narrow to assess such opportunities in more detail. 


\section{Diversifying the agenda}

Income from timber sales as an essential source of income and silvicultural work being conducted by the owners themselves describe the transitive edge of the transitivetransformative dimension (Lidestav, 2010). Earlier studies have suggested that compared to men, women are more conservation oriented (e.g. Uliczka et al., 2004; Ozanne et al., 2010), and they see more business opportunities related to forest tourism and health (Umaerus et al., 2019). Contrary to this, the results of this study support some of the earlier findings that not all female forest owners are conservation oriented, especially due to the importance of income from timber sales in rural areas (Vainio and Paloniemi, 2009; Butler et al., 2017). In the first meeting of the present female forest owner group, topics that were of interest to the group members were inquired. These topics mainly concerned forestry and silviculture. The data do not reveal the extent to which these interests were genuinely their own, and to what extent they may also have felt that timber-related interests were expected from them as active role models for rural women. The group's earlier activity in organizing a training event on the use of clearing saws speaks for genuine interest in wood production.

Moreover, according to the interviews with the forest owners, their mastery experiences focused on silvicultural actions such as planting or pre-commercial harvesting that aim for good timber quality, and the purpose of owning the forest was to obtain a livelihood via timber sales. Discussion topics outside the transitive dimension, such as the best places for picking mushroom, only came up in the discussions during breaks. This may also have been partly due to the participants' interests and partly due to the cultural (gendered) notion that mushrooms are a topic for breaks rather than core sessions. On the other hand, there were signs that the group meetings taught the women that there is no one right way to do anything, but that the customs of the men in a family and even the advices of forest extension specialists can be challenged (FO 1, FO 6).

According these and earlier results, women appear to think that if one wants to play the main role as a forest owner, the strategy should be rather transitive (Lidestav, 2010). It seems to be important to acquire and develop the same knowledge as men in order to take part in discussions and be heard. Participating in the male dominated discourse and activities has been the default way to become recognised. However, the idea of building self-efficacy among female forest owners is not to make women be, think or act in the same 
way as male forest owners. The idea is rather to empower women to discuss and promote the matters that are important to them in forests and forest ownership and to spark conversation (Fig. 2, trajectory number 2). According to these results, it appears that adequate self-efficacy enables female forest owners to participate in the masculine forest world, but not to transform it. The women interviewed here were only a fraction of female forest owners in Finland. The results might be different in the transitive - transformative dimension when interviewing female forest owners living outside farms, in families where income from timber sales is not as economically important. Staying on the transitive edge is not only a problem in discussion groups for female forest owners; it is equally important for male forest owners to diversify their discussions. In order to strengthen new openings, regardless of gender, the facilitator of a peer-learning group plays an important role in supporting and opening the space for discussion outside the transitive dimension, thereby fostering gender-equality discourses and practices.

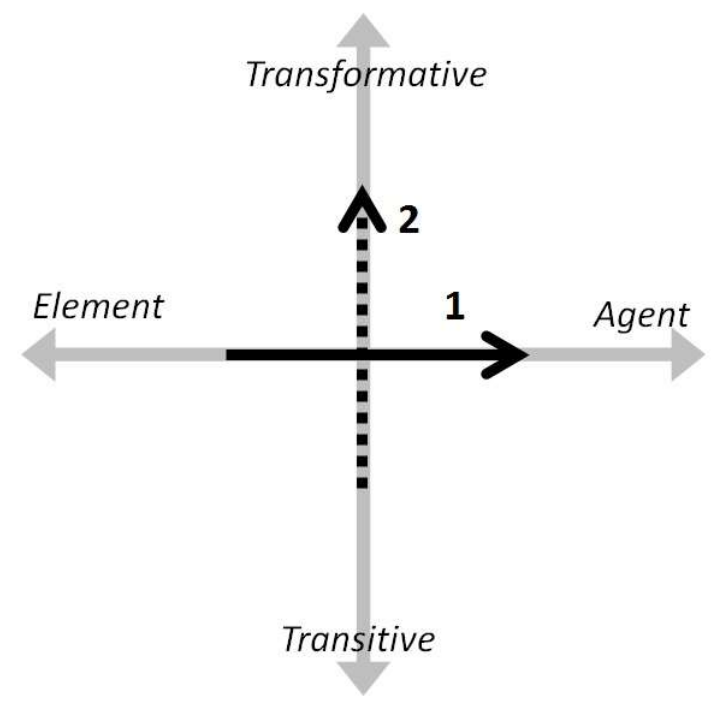

Figure 2. The main observed trajectories found in the present analysis of a Finnish rural female forest owners' peerlearning group: Trajectory 1 describes that peer-learning can support the change from Element towards Agent. The weak trajectory (number 2 ) describes that there is still a need to actively challenge the traditional ways of doing things and to diversify the discussion (from Transitive to Transformative).

\section{Conclusions}

During the past decades, the position and customary role of women in forestry and as forest owners have changed, and this change is ongoing. In this study, the female forest owners 
who participated in peer-learning settings were active in their own forests and eager to learn, but uncertain about their skills and knowledge; therefore, their husbands played the main role as forest owners. Uncertainty reduced the confidence of the female forest owners to participate in forest-related discussions or to share their views or knowledge, even with their peers. The results of this study suggest that during the peer-learning events, the women heard examples, became inspired and confident, and this led to increased selfefficacy. Peer-learning groups are safe environments that can especially support new forest owners; in this study, the group seemed to support the agency of the female forest owners, but not very strongly in a transformational manner. To strengthen and support the role of female forest owners in a masculine and even homosocial forest sector, visible role models, namely women who have taken responsibility for their forests, are needed. Forest extension institutions could support women by opening paths and giving space, even though building self-efficacy is in their own hands. For further societal impact these space-taking female forest owners would need to spread in the forest owner community and establish more equal discourses and practices, regardless of gender.

According to the results of this study, among the rural female forest owners, the direction and desired aim of learning seems to be the same silviculture and timber productionoriented knowledge as male forest owners have. Appreciation of the traditional, masculine forest sector might in some cases even prevent new uses and innovations in the forest sector. To break this stagnated culture, peer-learning groups would provide valuable opportunities to broaden the perspective outside the traditional forestry issues, find new openings and even business opportunities. The facilitator of a peer-learning group plays an important role in both encouraging forest owners to build self-efficacy and delving into new issues of interest among forest owners. Presenting different examples and giving space for owners who have practiced forestry in a different way might also encourage other owners to find their own way of being forest owners, regardless of gender. To establish new peerlearning groups, as well as to sustain already existing groups, there is a need for skilled forest-owner facilitators.

Disclosure statement: No potential conflict of interest was reported by the author(s). 


\section{Literature}

Andersson M, Håkansson C, Holmgren L. 2010. Non-industrial private forest owners' financial risk taking: Does gender matter? Scan J For Res. 25:6-13.

Andersson E, Lidestav G. 2016. Creating alternative spaces and articulating needs: Challenging gendered notions of forestry and forest ownership through women's networks. Forest Pol Econ. 67:38-44.

Arora-Jonsson S. 2014. Forty years of gender research and environmental policy: Where do we stand? Women Stud Int Forum. 47:295-308.

Bacchi C, Eveline J. 2010. Gender mainstreaming or diversity mainstreaming? The politics of 'doing'. In: Bacchi C, Eveline J. (eds.) Mainstreaming politics: Gendering practices and feminist theory, University of Adelaide, South Australia pp. 311-334.

Bandura A. 1977. Toward a unifying theory of behavioral change. Psychol Rev. 84(2):191215. doi: 10.1037/0033-295X.84.2.191.

Bandura A. 1997. Self-efficacy. The exercise of control. Worth Publishers. New York.

Bazeley P, Jackson K. 2013. Qualitative Data Analysis with NVivo. Sage Publications, 2nd ed., London.

Brandth B, Haugen M.S. 1998. Breaking into a Masculine Discourse. Women and Farm Forestry. Sociol Ruralis. 38:427-442.

Brandth B, Follo G, Haugen M. S. 2004. Women in forestry: Dilemmas of a separate women's organization. Scan J For Res. 19(5):466-472.

Butler SM, Huff ES, Snyder SA, Butler BJ, Tyrrell M. 2016. The Role of Gender in Management Behaviors on Family Forest Lands in the United States. J Forest. 116(1):3240. https://doi.org/10.5849/jof.2016-076R2

Eisen MJ. 2001. Peer-Based Learning: A New-Old Alternative to Professional Development. Adult Learning. 12(1): 9-10. doi: 10.1177/104515950101200105.

Eriksson L. 2018. Explaining gender differences in private forest risk management. Scan J For Res. 33(7):716-723.

Flygare IA. 1999. Generations and continuity. Family farming in two Swedish grain-growing districts in 20th century. Doctoral dissertation. Upplands Fornminnesförenings Tidskrift 54. Upplands Fornminnesförenings Förlag. (In Swedish with English summary.) 
Flygare IA. 2001. Links, agents and alternatives. Generations of women in twentieth century agriculture. In Liljewall B, Niskanen K, Sjöberg M. (Eds.), Kvinnor och jord. Arbete och ägande frånmedeltid till nutid [Women and the land. Work and ownership from the Middle Ages to the present day]. Skrifter om skogs- och lantbrukshistoria (pp. 13-30). Lund: Nordiska museets förlag.

Follo G, Lidestav G, Ludvig A, Vilkriste L, Hujala T, Karppinen H, Didolot F, Mizaraite D. 2017. Gender in European forest ownership and management: reflections on women as "New forest owners". Scan J For Res. 32(2):174-184. doi: 10.1080/02827581.2016.1195866

Hackett G, Betz NE. 1981. A self-efficacy approach to the career development of women. J Vocat Behav. 18(3):326-339. https://doi.org/10.1016/0001-8791(81)90019-1.

Häggqvist P, Lejon SB, Lidestav G. 2014. Look at what they do - a revised approach to communication strategy towards private forest owners. Scan J For Res. 29(7):697-706. doi: 10.1080/02827581.2014.960894.

Hamunen K, Appelstrand M, Hujala T, Kurttila M, Sriskandarajah N, Vilkriste L, Westberg L, Tikkanen J. 2015. Defining peer-to-peer learning - from an old "art of practice" to a new mode of forest owner extension? Journal of Agricultural Education and Extension. 21(4):293-307. doi: 10.1080/1389224X.2014.939199

Hankivsky O. 2005. Gender vs. diversity mainstreaming: A preliminary examination of the role and transformative potential of feminist theory. Can J Polit Sci. 38(4):977-1001.Huff E. 2017. A National Perspective on Women Owning Woodlands (WOW) Networks. J Extension. 55(2).

Johansson K, Andersson E, Johansson M, Lidestav G. 2019. Conditioned openings and restraints: The meaning-making of women professionals breaking into the maledominated sector of forestry. Gend Work Organ. https://doi.org/10.1111/gwao.12403

Karppinen H, Berghäll S. 2015. Forest owners' stand improvement decisions: Applying the Theory of Planned Behavior. Forest Pol Econ. 50:275-284.

Karppinen H, Hänninen H. 2017. Metsien omistaminen ja käyttö - onko sukupuolella väliä? Metsätieteen aikakauskirja. https://doi.org/10.14214/ma.7708 (In Finnish).

Karppinen H, Hänninen H, Horne P. 2020. Suomalainen metsänomistaja 2020 [Finnish Forest Owner 2020]. Luonnonvara- ja biotalouden tutkimus 30/2020. (In Finnish.) 74p. 
Knoot TG, Rickenbach M. 2011. Best management practices and timber harvesting: the role of social networks in shaping landowner decisions. Scan J For Res. 26(2):171-182. doi: 10.1080/02827581.2010.545827.

Kueper AM, Sagor ES, Becker DR. 2013. Learning from Landowners: Examining the Role of Peer Exchange in Private Landowner Outreach through Landowner Networks. Soc Natur Resour. 26(8):912-930. doi: 10.1080/08941920.2012.722748.

Kuuluvainen J, Karppinen H, Hänninen H, Uusivuori J. 2014. Effects of gender and length of land tenure on timber supply in Finland. J Forest Econ. 20:363-379. doi: 10.1016/j.jfe.2014.10.002.

Lidestav G. 1998. Women as non-industrial private forest landowners in Sweden, Scan J For Res. 13(1-4):66-73.

Lidestav G, Wästerlund D. (eds). 1999. Women and Forestry, Proceedings of the Nordic Baltic Workshop in Balsjö, Sweden, December 7-9, 1998. TemaNord 1999: 571, Nordic Council of Ministers, Copenhagen.

Lidestav G. 2010. In competition with a brother: Women's inheritance positions in contemporary Swedish family forestry, Scan J For Res. 25:14-24.

Lidestav G, Berg Lejon S. 2013. Harvesting and silvicultural activities in Swedish family forestry-behavior changes from a gender perspective, Scan J For Res. 28(2):136-142.

Lidestav G, Ekström M. 2000. Introducing gender in studies on management behaviour among non-industrial private forest owners, Scan J For Res. 15(3):378-386.

Lidestav G, Nordfjell T. 2005. A Conceptual Model for Understanding Social Practices in Family Forestry. Small-scale Forest Economics, Management and Policy. 4(4):391-408. Available at: https://link.springer.com/content/pdf/10.1007\%2Fs11842-005-0024-7.pdf Ma Z, Kittredge DB, Catanzaro P. 2012. Challenging the Traditional Forestry Extension Model: Insights from the Woods Forum Program in Massachusetts. Small-scale Forestry. 11(1):87-100. doi: 10.1007/s11842-011-9170-2.

Markowski-Lindsay M, Catanzaro P, Zimmerer R, Kittredge D, Markowitz E, Chapman DA. 2020. Northeast Family Forest Owner Gender Differences in Land-Based Estate Planning and the Role of Self-Efficacy. J Forest. 59-69. doi:10.1093/jofore/fvz058

McPherson M, Smith-Lovin L, Cook JM. 2001. Birds of Feather: Homophily in Social Networks. Annu Rev Sociol. 27:415-444. doi:10.1146/annurev.soc.27.1.415 
Ozanne L, Humphrey C, Smith P. 1999. Gender, Environmentalism, and Interest in Forest Certification: Mohai's Paradox Revisited. Soc Natur Resour. 12(6):613-622.

DOI: $10.1080 / 089419299279470$

Pajares F. 2002. Gender and Perceived Self-efficacy in Self-regulated Learning. Theor Pract. 41(2):116-125.

Redmore LE, Tynon JF. 2011. Women owning woodlands: Understanding women's roles in forest ownership and management, J Forest. 109(5):255-259.

Resurreccion BP, Elmhirst R. 2012. Gender, environment and natural resource management: New dimensions, new debates. In: Resurreccion, B. P., Elmhirst, R (eds.) Gender and Natural Resource Management (pp. 19-36). Routledge, London.

Schubert JR, Mayer AL. 2012. Peer influence of non-industrial private forest owners in the Western Upper Peninsula of Michigan. Open Journal of Forestry. 2(3):150158. http://dx.doi.org/10.4236/ojf.2012.23018

Schunk DH, Meece JL. 2006. Self-Efficacy Development in Adolescense. In: Pajares F, Urdan T. (eds.) Self-Efficacy Beliefs of Adolescents (pp. 71-96). Greenwich, Connecticut: Information Age Publishing.

Suoninen E. 2012. Identiteettien rakentuminen [Constitution of identities]. In: Jokinen A, Juhila K, Suoninen E. (eds.) Kategoriat, kulttuuri \& moraali. Vastapaino, Tampere. 296 p. (In Finnish.)

Topping KJ. 2005, Trends in Peer Learning. Educ Psychol-UK. 25(6):631-645. doi: $10.1080 / 01443410500345172$.

Törnqvist T. 1995. Inheritors of the woodlands. A sociological study of private, non-industrial forest ownership (Rep. 41). Dissertation, Department of Forestry Industry Market Studies, Swedish University of Agricultural Sciences, Uppsala. (In Swedish with English summary.)

Uliczka H, Angelstam P, Jansson G, Bro A. 2004. Non-industrial private forest owners' knowledge of and attitudes towards nature conservation. Scan J For Res. 19(3):274-288. https://doi.org/10.1080/02827580410029318

Umaerus P, Lidestav G, Eriksson LO, Högvall Nordin M. 2013. Gendered business activities in family farm forestry: From round wood delivery to health service. Scan J For Res. 28(6):596-607. 
Umaerus P, Nordin MH, Lidestav G. 2019. Do female forest owners think and act "greener"?. Forest Pol Econ. 99:52-58. https://doi.org/10.1016/j.forpol.2017.12.001

Vainio A, Paloniemi R. 2009. Sukupuoli- ja luontokäsitykset suomalaisen metsänomistajuuden osana: diskurssianalyyttinen näkökulma. [Conceptions of gender and nature in constructing forest ownership: a discourse analytic perspective]. Alue ja ympäristö. $38(2): 3-12$.

Vainio A, Paloniemi R. 2013. Adapting to the gender order: Voluntary conservation by forest owners in Finland. Land Use Policy. 35:247-256. doi: 10.1016/j.landusepol.2013.05.017

Vehviläinen S. 2014. Ohjaustyön opas [A guide for supervision], Gaudeamus, 239p. (In Finnish.)

Wengraf T. 2001. Qualitative Research Interviewing. Middlesex University, Sage

Publications, London.

$424 p$.

Verloo M. 2005. Displacement and Empowerment: Reflections on the Concept and Practice of the Council of Europe Approach to Gender Mainstreaming and Gender Equality. Social Politics: International Studies in Gender, State and Society. 12(3):344-365.

West C, Zimmerman DH. 1987. Doing gender. Gender Soc. 1(2):125-151.

West C, Zimmerman DH. 2009. Accounting for doing gender. Gender Soc. 23(1):112-122.

West PC, Fly JM, Blahna DJ, Carpenter EM. 1988. The Communication and Diffusion of NIPF Management Strategies. North J Appl For. 5(4):265-270.

Wood R, Bandura A. 1989. Social Cognitive Theory Organizational Management. Acad Manage Rev. 14(3):361-384.

Zimmerman BJ. 2000. Self-efficacy: An Essen 
Appendix 1. Themes of the interviews with forest owners

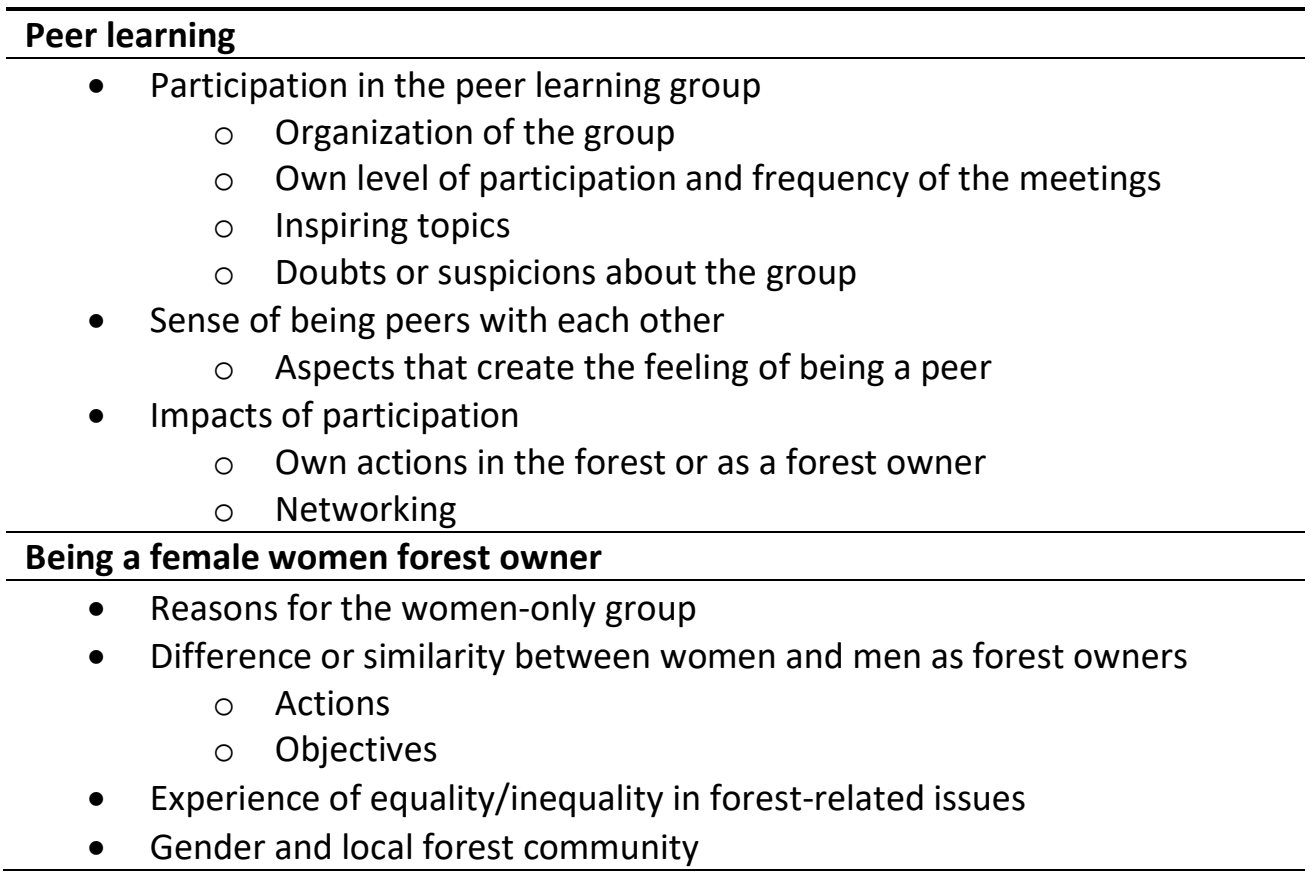

Appendix 2. Coding classes based on theoretical background

\begin{tabular}{|c|c|c|}
\hline $\begin{array}{l}\text { Theoretical } \\
\text { background/concepts }\end{array}$ & First coding classes & Elaborated coding classes \\
\hline \multicolumn{3}{|c|}{ Role of female forest owners } \\
\hline $\begin{array}{ll}\text { - } & \text { Doing gender } \\
\text { - } & \text { Mastery } \\
\text { experiences }\end{array}$ & $\begin{array}{l}\text { - Role as a female } \\
\text { forest owner } \\
\text { - Changes in the role } \\
\text { of female forest } \\
\text { owners }\end{array}$ & 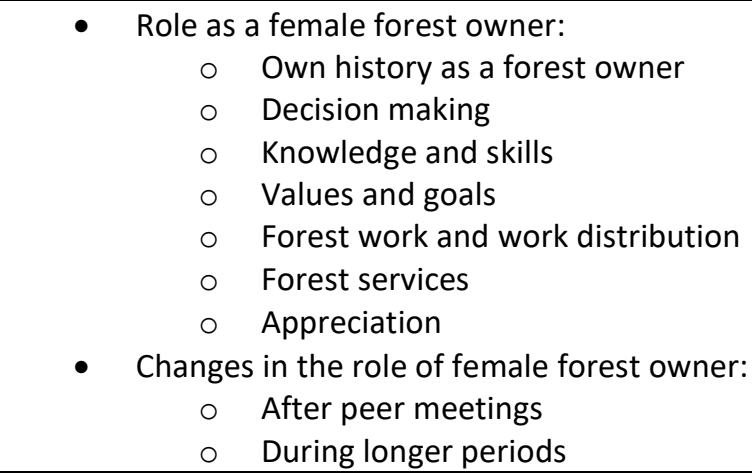 \\
\hline \multicolumn{3}{|l|}{ Peer learning } \\
\hline $\begin{array}{ll}\text { - } & \text { Peer learning } \\
\text { - } & \text { Vicarious } \\
\text { experiences, } \\
\text { persuasion }\end{array}$ & $\begin{array}{l}\text { - } \quad \text { Reasons for peer } \\
\text { groups } \\
\text { - Experiences of peer } \\
\text { groups }\end{array}$ & $\begin{array}{l}\text { - } \quad \text { Peer features that came up } \\
\text { - } \quad \text { Feelings in the group and team spirit } \\
\text { - } \quad \text { Reasons for joining the group } \\
\text { - } \quad \text { Suspicions about joining the group } \\
\text { - } \quad \text { Experiences and support from peers }\end{array}$ \\
\hline \multicolumn{3}{|c|}{ Impacts of peer meetings } \\
\hline $\begin{array}{ll} & \begin{array}{l}\text { Changes in } \\
\text { self-efficacy }\end{array} \\
\text { - } & \begin{array}{l}\text { New mastery } \\
\text { experiences }\end{array}\end{array}$ & $\begin{array}{ll}\text { - } & \text { Learning and } \\
\text { increased } \\
\text { information } \\
\text { - } \quad \text { Concrete actions } \\
\text { - } \quad \text { Empowerment and } \\
\text { increased self- } \\
\text { efficacy }\end{array}$ & $\begin{array}{l}\text { - } \quad \text { Learning and increased information } \\
\text { - } \quad \text { Concrete actions } \\
\text { - } \quad \text { Empowerment and increased self-efficacy }\end{array}$ \\
\hline
\end{tabular}

